\title{
Substitution of Chemical Fertilizers with Organic Manure and Biofertilizers in Fenugreek (Trigonella foenum-graecum L.) on Medium Black Calcareous Clayey Soil
}

\author{
V.N. Raiyani*, P.K. Chovatia and K.B. Kamani \\ Department of Agronomy, College of Agriculture, Junagadh Agricultural University, \\ Junagadh-362 001, Gujarat, India \\ *Corresponding author
}

\section{A B S T R A C T}

\section{Keywords}

FYM, Rhizobium, PSB, KSB,

Nitrogen,

Phosphorus,

Potassium, Yield

Article Info

Accepted:

17 June 2019

Available Online:

10 July 2019
A field experiment entitled "Substitution of chemical fertilizers with organic manure and biofertilizers in fenugreek (Trigonella foenum-graecum L.) on medium black calcareous clayey soil" was carried out during rabi season of 2016-17 at Junagadh. The experimental results revealed that significantly higher values of Nutrient content and uptake in seed and stover of fenugreek, microbial count at initial, 30 DAS and at harvest of crop and available nitrogen, phosphorus and potassium status in soil after harvest were recorded under the treatment $\mathrm{T}_{10} \mathrm{FYM} 4 \mathrm{t} / \mathrm{ha}+$ Rhizobium (seed inoculation) $+\mathrm{PSB}+\mathrm{KSB}$ (soil application), being at par with treatments $\mathrm{T}_{2}\left(20-40-00 \mathrm{~kg} \mathrm{~N}-\mathrm{P}_{2} \mathrm{O}_{5}-\mathrm{K}_{2} \mathrm{O} / \mathrm{ha}\right), \mathrm{T}_{7}$ (FYM 4 t/ha + Rhizobium $+\mathrm{PSB}), \mathrm{T}_{8}(\mathrm{FYM} 4 \mathrm{t} / \mathrm{ha}+$ Rhizobium $+\mathrm{KSB})$ and $\mathrm{T}_{9}(\mathrm{FYM} 4 \mathrm{t} / \mathrm{ha}+\mathrm{PSB}+$ $\mathrm{KSB})$.

\section{Introduction}

Fenugreek (Trigonella foenum-graecum L.) is medicinally important seed spice belonging to the family leguminosae. Fenugreek locally known as Methi. Fenugreek is considered to have originated in South Eastern Europe and far West Asia, has been grown in India, part of North African counties, Argentina, France, Morocco, Lebanon. India is the one of major producer of fenugreek is a multipurpose crop grown in Northern Indian states like
Rajasthan, Gujarat, Madhya Pradesh, Maharashtra, Haryana, Punjab, Uttar Pradesh and Andhra Pradesh, during winter season. In Gujarat, fenugreek occupied an area of 6257 hectares producing 15138 tonnes of seeds. The major fenugreek growing districts in Gujarat are Banaskantha, Patan and Kheda (Anon., 2017). Every part of this plant is utilized as leafy vegetable, fodder and condiments (Khiriya and Singh, 7). Its seeds are a good source of protein, vitamins, alkaloid trigonellin and essential oil and have an 
immense medicinal value particularly against digestive disorders (Bhunia et al., 2006). Seeds are used for the treatment of diabetes, dysentery, diarrhoea and rickets. Diosgenin, which is extracted from the seeds is used in synthesis of sex hormones. Its roots are endowed with mini factory to synthesize nitrogen for plant. Thus, its cultivation enriches the soil in nitrogen.

Indiscriminate use of chemical fertilizers and chemical pesticides contributed in loss of soil productivity along with addition of salts to the soil. Reliance on chemical fertilizers for upcoming agricultural growth would mean further loss in soil quality, likelihoods of water contamination and unmanageable burden on agricultural system (Rajasekaran et al., 2012).

Bio fertilizer play an important strategy in order to improve the biological, chemical and physical conditions of the soil, acquiring each time greater importance not only for the yields usually reached but also for the economic application and contribution to environment protection. Biofertilizers provide most of the macro- and micro-nutrients through biological nitrogen fixation, phosphate solubilization and potassium mobilization or mineralization, secretion of plant growth promoting substances, production of antibiotics and decomposition of organic waste materials in the soil (Sinha et al., 2014) and thereby enhancing nutrient uptake and augmenting tolerance against moisture deficit stress. Farm yard manure improved soil fertility, growth and yield of plant.

\section{Materials and Methods}

The experiment was conducted in D-4 plot of Instructional Farm, Department of Agronomy, Junagadh Agricultural University, Junagadh during Rabi 2016-17 to study the "Substitution of chemical fertilizers with organic manure and biofertilizers in fenugreek (Trigonella foenum-graecum L.) on medium black calcareous clayey soil". The soil of the experimental plot was clayey in texture and slightly alkaline in reaction with $\mathrm{pH} 8.0$ and EC $0.56 \mathrm{dS} / \mathrm{m}$. The soil was low in available nitrogen $(285 \mathrm{~kg} / \mathrm{ha})$, high in available phosphorus $(68 \mathrm{~kg} / \mathrm{ha})$ and medium in available potash $(232 \mathrm{~kg} / \mathrm{ha})$. Ten treatments comprising of $\mathrm{T}_{1}$ (Control), $\mathrm{T}_{2}$ (20-40-00 kg $\mathrm{N}-\mathrm{P}_{2} \mathrm{O}_{5}-\mathrm{K}_{2} \mathrm{O} / \mathrm{ha}$ ), $\mathrm{T}_{3}$ (FYM 4 t/ha), $\mathrm{T}_{4}$ (FYM 4 $\mathrm{t} / \mathrm{ha}+$ Rhizobium $), \mathrm{T}_{5}(\mathrm{FYM} 4 \mathrm{t} / \mathrm{ha}+\mathrm{PSB}), \mathrm{T}_{6}$ $(\mathrm{FYM} 4 \mathrm{t} / \mathrm{ha}+\mathrm{KSB}), \mathrm{T}_{7}(\mathrm{FYM} 4 \mathrm{t} / \mathrm{ha}+$ Rhizobium + PSB), $\mathrm{T}_{8}$ (FYM 4 t/ha + Rhizobium + KSB), $\mathrm{T}_{9}(\mathrm{FYM} 4 \mathrm{t} / \mathrm{ha}+\mathrm{PSB}+$ $\mathrm{KSB})$ and $\mathrm{T}_{10}$ (FYM 4 t/ha + Rhizobium + $\mathrm{PSB}+\mathrm{KSB}$ ) with three replications.

The improved variety "Gujarat Fenugreek-2" was used for sowing with seed rate of 25 $\mathrm{kg} / \mathrm{ha}$ on $18^{\text {th }}$ November during 2016. The seeds were placed at $3-5 \mathrm{~cm}$ depth, keeping inter row spacing of $30 \mathrm{~cm}$ and covered with the soil. The crop was uniformly fertilized with $20 \mathrm{~kg} / \mathrm{ha}$ nitrogen and $40 \mathrm{~kg} / \mathrm{ha} \mathrm{P}_{2} \mathrm{O}_{5}$ in the form of urea and di-ammonium phosphate, respectively as a basal application just before sowing. It is applied in only treatment plot.

\section{Results and Discussion}

\section{Effect on content and uptake of nutrients in seed and stover of fenugreek}

Nitrogen, Phosphorus and potassium content and uptake in seed and Nitrogen, Phosphorus and Potassium content and uptake in stover were significantly influenced by different treatments (Table 1 and 2).

Among the different treatments, significantly higher $\mathrm{N}$ content in seed and stover was recorded under the $\mathrm{T}_{10}$ (FYM 4 t/ha + Rhizobium + PSB + KSB) and it was observed statistically analogous to treatment $\mathrm{T}_{2}$ (20-40$\left.00 \mathrm{~kg} \mathrm{~N}-\mathrm{P}_{2} \mathrm{O}_{5}-\mathrm{K}_{2} \mathrm{O} / \mathrm{ha}\right), \mathrm{T}_{4}$ (FYM 4 t/ha + Rhizobium) and $\mathrm{T}_{7}$ (FYM $4 \mathrm{t} / \mathrm{ha}+$ Rhizobium 
+ PSB). While, the lowest value of $\mathrm{N}$ content in seed and stover were observed under the control treatment $\left(\mathrm{T}_{1}\right)$.

$\mathrm{N}$ uptake by seed and stover significantly higher with treatment $\mathrm{T}_{10}$ (FYM 4 t/ha + Rhizobium + PSB + KSB) and it was found statistically analogous to treatment $\mathrm{T}_{2}$ (20-40$00 \mathrm{~kg} \mathrm{~N}-\mathrm{P}_{2} \mathrm{O}_{5}-\mathrm{K}_{2} \mathrm{O} / \mathrm{ha}$ ) with respect to $\mathrm{N}$ uptake by seed. While, treatment $\mathrm{T}_{2}$ (20-40-00 $\mathrm{kg} \mathrm{N}-\mathrm{P}_{2} \mathrm{O}_{5}-\mathrm{K}_{2} \mathrm{O} / \mathrm{ha}$ ) and $\mathrm{T}_{7}(\mathrm{FYM} 4 \mathrm{t} / \mathrm{ha}+$ Rhizobium + PSB) with regards to $\mathrm{N}$ uptake by stover.

While, the lowest value of $\mathrm{N}$ uptake by seed and stover were observed under the control treatment $\left(\mathrm{T}_{1}\right)$. This increase $\mathrm{N}$ content in seed and stover might be due to the decomposition of applied FYM. The reason for increase in nitrogen content in seed with Rhizobium inoculation may be attributed due to higher nodulation which in turn might have resulted into higher supply of nitrogen to the crop.

Significantly highest $\mathrm{P}$ content in seed and stover was recorded under the treatment $T_{10}$ (FYM 4 t/ha + Rhizobium + PSB + KSB) and it was found statistically analogous to treatment $\mathrm{T}_{2}$ (20-40-00 kg N-P $\left.\mathrm{O}_{5}-\mathrm{K}_{2} \mathrm{O} / \mathrm{ha}\right)$, $\mathrm{T}_{5}$ (FYM 4 t/ha + PSB), T $($ FYM 4 t/ha + Rhizobium + PSB) and $\mathrm{T}_{9}(\mathrm{FYM} 4 \mathrm{t} / \mathrm{ha}+\mathrm{PSB}$ $+\mathrm{KSB})$.

While, the lowest value of $\mathrm{P}$ content in seed and stover were observed under the control treatment $\left(\mathrm{T}_{1}\right)$.

$\mathrm{P}$ uptake by seed and stover significantly higher with treatment $\mathrm{T}_{10}$ (FYM 4 t/ha + Rhizobium + PSB + KSB) and it was found statistically analogous to treatment $\mathrm{T}_{2}$ (20-40$00 \mathrm{~kg} \mathrm{~N}-\mathrm{P}_{2} \mathrm{O}_{5}-\mathrm{K}_{2} \mathrm{O} / \mathrm{ha}$ ), while $\mathrm{P}$ content in stover also at par with treatment $\mathrm{T}_{7}$ (FYM 4 $\mathrm{t} /$ ha + Rhizobium + PSB). While the lowest value of $\mathrm{P}$ uptake by seed and stover were observed under the control treatment $\left(\mathrm{T}_{1}\right)$.
This increase $\mathrm{P}$ content in seed and stover might be due to the PSB solubilized the fixed soil phosphorus and readily hydrolysed the organophosphate and degraded them in the soil and increase the availability of fixed $\mathrm{P}$ and applied $\mathrm{P}$ to the plant owing to its favourable effects on division and multiplication of cells.

Among the different treatments, significantly higher $\mathrm{K}$ content in seed and stover was recorded under the $\mathrm{T}_{10}$ (FYM 4 t/ha + Rhizobium + PSB + KSB) and it was found statistically at par with treatment $\mathrm{T}_{2}(20-40-00$ $\left.\mathrm{kg} \mathrm{N}-\mathrm{P}_{2} \mathrm{O}_{5}-\mathrm{K}_{2} \mathrm{O} / \mathrm{ha}\right), \mathrm{T}_{6}(\mathrm{FYM} 4 \mathrm{t} / \mathrm{ha}+\mathrm{KSB})$, $\mathrm{T}_{8}(\mathrm{FYM} 4 \mathrm{t} / \mathrm{ha}+$ Rhizobium $+\mathrm{KSB})$ and $\mathrm{T}_{9}$ (FYM 4 t/ha + PSB + KSB).

While, the lowest value of $\mathrm{K}$ content in seed and stover were observed under the control treatment $\left(\mathrm{T}_{1}\right)$.

$\mathrm{K}$ uptake by seed and stover significantly higher with treatment $\mathrm{T}_{10}(\mathrm{FYM} 4 \mathrm{t} / \mathrm{ha}+$ Rhizobium + PSB + KSB) and it was found statistically analogous to treatment $\mathrm{T}_{2}$ (20-40$00 \mathrm{~kg} \mathrm{~N}-\mathrm{P}_{2} \mathrm{O}_{5}-\mathrm{K}_{2} \mathrm{O} / \mathrm{ha}$ ). While, the lowest value of $\mathrm{K}$ uptake by seed and stover were observed under the control treatment $\left(\mathrm{T}_{1}\right)$. This increase $\mathrm{K}$ content in seed and stover might be due to the response of KSB may be attributed to mobilization of $\mathrm{K}$ from soil because of secretion of organic acids by the bacterial strains, thereby enhanced plant growth and development, and finally greater acquisition of nutrients. The results are supported by other workers who have observed increase in plant assimilation of $\mathrm{K}$ by the use of potassium solubilizing microorganisms in soil.

Positively nutrient content and uptake in seed and stover of N, P and $\mathrm{K}$ are influenced by various FYM and biofertilizer treatments these similar observations were also reported by Lakpale and Shrivastava (2007) and Patil et al., (2008). 
Table.1 Effect of different treatments on content of nutrients in seed and stover of fenugreek

\begin{tabular}{|l|l|l|l|l|l|l|}
\hline \multirow{2}{*}{ Treatments } & \multicolumn{3}{|c|}{ Nutrient content in seed (\%) } & \multicolumn{3}{c|}{ Nutrient content in stover (\%) } \\
\cline { 2 - 7 } & $\mathrm{N}$ & $\mathrm{P}$ & $\mathrm{K}$ & $\mathrm{N}$ & $\mathrm{P}$ & $\mathrm{K}$ \\
\hline $\mathbf{T}_{\mathbf{1}}$ & 3.03 & 0.35 & 0.50 & 1.99 & 0.20 & $\mathbf{0 . 5 8}$ \\
\hline $\mathbf{T}_{\mathbf{2}}$ & 3.82 & 0.45 & 0.61 & 2.44 & 0.28 & $\mathbf{0 . 7 1}$ \\
\hline $\mathbf{T}_{\mathbf{3}}$ & 3.11 & 0.37 & 0.52 & 2.08 & 0.21 & $\mathbf{0 . 5 9}$ \\
\hline $\mathbf{T}_{\mathbf{4}}$ & 3.62 & 0.38 & 0.53 & 2.28 & 0.23 & $\mathbf{0 . 6 2}$ \\
\hline $\mathbf{T}_{\mathbf{5}}$ & 3.31 & 0.40 & 0.54 & 2.13 & 0.26 & $\mathbf{0 . 6 1}$ \\
\hline $\mathbf{T}_{\mathbf{6}}$ & 3.22 & 0.37 & 0.58 & 2.13 & 0.22 & $\mathbf{0 . 6 6}$ \\
\hline $\mathbf{T}_{\mathbf{7}}$ & 3.67 & 0.43 & 0.54 & 2.33 & 0.27 & $\mathbf{0 . 6 3}$ \\
\hline $\mathbf{T}_{\mathbf{8}}$ & 3.55 & 0.39 & 0.61 & 2.20 & 0.24 & $\mathbf{0 . 7 0}$ \\
\hline $\mathbf{T}_{\mathbf{9}}$ & 3.44 & 0.42 & 0.59 & 2.20 & 0.25 & $\mathbf{0 . 6 8}$ \\
\hline $\mathbf{T}_{\mathbf{1 0}}$ & 3.97 & 0.47 & 0.64 & 2.52 & 0.29 & $\mathbf{0 . 7 3}$ \\
\hline S.Em. & 0.13 & 0.02 & 0.03 & 0.10 & 0.01 & $\mathbf{0 . 0 3}$ \\
\hline CD at 5 \% & 0.39 & 0.07 & 0.09 & 0.31 & 0.04 & $\mathbf{0 . 0 9}$ \\
\hline CV \% & $\mathbf{6 . 5 6}$ & $\mathbf{9 . 5 2}$ & $\mathbf{8 . 8 6}$ & $\mathbf{8 . 0 4}$ & $\mathbf{8 . 4 5}$ & $\mathbf{8 . 3 1}$ \\
\hline
\end{tabular}

Table.2 Effect of different treatments on uptake of nutrients in seed and stover of fenugreek

\begin{tabular}{|l|c|c|c|c|c|c|}
\hline \multirow{2}{*}{ Treatments } & \multicolumn{2}{|c|}{ Nutrient uptake in seed (\%) } & \multicolumn{3}{c|}{ Nutrient uptake in stover (\%) } \\
\cline { 2 - 7 } & $\mathrm{N}$ & $\mathrm{P}$ & $\mathrm{K}$ & $\mathrm{N}$ & $\mathrm{P}$ & $\mathbf{K}$ \\
\hline $\mathbf{T}_{\mathbf{1}}$ & 30.93 & 3.57 & 5.10 & 37.82 & 3.80 & $\mathbf{1 1 . 0 2}$ \\
\hline $\mathbf{T}_{\mathbf{2}}$ & 62.26 & 7.35 & 10.0 & 67.51 & 7.75 & $\mathbf{1 9 . 6 5}$ \\
\hline $\mathbf{T}_{\mathbf{3}}$ & 38.83 & 4.64 & 6.57 & 44.25 & 4.46 & $\mathbf{1 2 . 5 3}$ \\
\hline $\mathbf{T}_{\mathbf{4}}$ & 49.07 & 5.14 & 7.15 & 56.11 & 5.70 & $\mathbf{1 5 . 3 8}$ \\
\hline $\mathbf{T}_{\mathbf{5}}$ & 43.59 & 5.29 & 7.16 & 48.41 & 5.89 & $\mathbf{1 3 . 6 6}$ \\
\hline $\mathbf{T}_{\mathbf{6}}$ & 41.36 & 4.76 & 7.45 & 46.81 & 4.84 & $\mathbf{1 4 . 5 1}$ \\
\hline $\mathbf{T}_{\mathbf{7}}$ & 55.12 & 6.32 & 8.39 & 62.31 & 7.18 & $\mathbf{1 6 . 7 6}$ \\
\hline $\mathbf{T}_{\mathbf{8}}$ & 48.04 & 5.28 & 8.32 & 50.65 & 5.53 & $\mathbf{1 6 . 1 2}$ \\
\hline $\mathbf{T}_{\mathbf{9}}$ & 47.86 & 5.89 & 8.24 & 55.97 & 6.35 & $\mathbf{1 7 . 2 7}$ \\
\hline $\mathbf{T}_{\mathbf{1 0}}$ & 67.87 & 8.05 & 10.9 & 70.90 & 8.09 & $\mathbf{2 0 . 4 3}$ \\
\hline S.Em.+ & 2.58 & 0.36 & 0.68 & 4.06 & 0.33 & $\mathbf{0 . 8 1}$ \\
\hline CD at 5 \% & 7.66 & 1.07 & 2.01 & 12.06 & 0.99 & $\mathbf{2 . 4 1}$ \\
\hline CV \% & $\mathbf{9 . 1 0}$ & $\mathbf{1 0 . 9 2}$ & $\mathbf{1 4 . 6 4}$ & $\mathbf{1 2 . 9 0}$ & $\mathbf{9 . 6 0}$ & $\mathbf{8 . 8 6}$ \\
\hline
\end{tabular}


Table.3 Effect of different treatments on microbial counts and available nutrients status after harvest of fenugreek

\begin{tabular}{|c|c|c|c|c|c|c|c|c|c|}
\hline \multirow[t]{2}{*}{$\begin{array}{c}\text { Treatme } \\
\text { nts }\end{array}$} & \multicolumn{2}{|c|}{$\begin{array}{l}\text { Rhizobium count } \\
\qquad\left(1 \times 10^{6}\right) \text { at }\end{array}$} & \multicolumn{2}{|c|}{$\begin{array}{l}\text { PSB count } \\
\left(1 \times 10^{6}\right) \text { at }\end{array}$} & \multicolumn{2}{|c|}{$\begin{array}{l}\text { KSB count } \\
\left(1 \times 10^{6}\right) \text { at }\end{array}$} & \multicolumn{3}{|c|}{$\begin{array}{c}\text { Soil available } \\
\text { (kg/ha) }\end{array}$} \\
\hline & $\begin{array}{c}60 \\
\text { DAS }\end{array}$ & Harvest & $\begin{array}{c}60 \\
\text { DAS }\end{array}$ & Harvest & $\begin{array}{c}60 \\
\text { DAS }\end{array}$ & Harvest & $\mathbf{N}$ & $\mathbf{P}_{2} \mathbf{O}_{5}$ & $\mathbf{K}_{2} \mathbf{O}$ \\
\hline $\mathbf{T}_{1}$ & 1.99 & 0.20 & 30.93 & 3.57 & 2.93 & 3.70 & 234 & 52.31 & 196 \\
\hline $\mathbf{T}_{2}$ & 2.44 & 0.28 & 62.26 & 7.35 & 3.27 & 3.95 & 279 & 64.97 & 224 \\
\hline $\mathbf{T}_{\mathbf{3}}$ & 2.08 & 0.21 & 38.83 & 4.64 & 3.56 & 4.13 & 236 & 56.30 & 198 \\
\hline $\mathbf{T}_{4}$ & 2.28 & 0.23 & 49.07 & 5.14 & 4.18 & 5.01 & 256 & 58.30 & 201 \\
\hline $\mathbf{T}_{5}$ & 2.13 & 0.26 & 43.59 & 5.29 & 3.96 & 4.78 & 242 & 62.30 & 200 \\
\hline$T_{6}$ & 2.13 & 0.22 & 41.36 & 4.76 & 5.07 & 6.03 & 239 & 57.63 & 211 \\
\hline $\mathbf{T}_{7}$ & 2.33 & 0.27 & 55.12 & 6.32 & 4.19 & 5.06 & 271 & 64.33 & 205 \\
\hline $\mathbf{T}_{8}$ & 2.20 & 0.24 & 48.04 & 5.28 & 5.33 & 6.41 & 265 & 59.33 & 218 \\
\hline $\mathbf{T}_{9}$ & 2.20 & 0.25 & 47.86 & 5.89 & 5.22 & 6.26 & 249 & 62.97 & 214 \\
\hline $\mathbf{T}_{10}$ & 2.52 & 0.29 & 67.87 & 8.05 & 5.42 & 6.56 & 283 & 65.30 & 227 \\
\hline S.Em. \pm & 0.10 & 0.01 & 2.58 & 0.36 & 0.40 & 0.43 & 8.28 & 1.84 & 6.91 \\
\hline $\begin{array}{l}\text { CD at } 5 \\
\%\end{array}$ & 0.31 & 0.04 & 7.66 & 1.07 & 1.20 & 1.29 & 24.59 & 5.47 & 20.53 \\
\hline CV \% & 8.04 & 8.45 & 9.10 & 10.92 & 16.22 & 14.49 & 5.6 & 5.28 & 5.7 \\
\hline
\end{tabular}

Effect on available nutrients and microbial count in the soil after harvest

Soil microbial count viz., Rhizobium count PSB count and KSB count at 60 DAS and after harvest of fenugreek and available nitrogen, phosphorus and potash status in the soil after the harvest of the fenugreek crop were significantly increased by the different treatments. Bulk density did not influence by different FYM and biofertilizer treatments (Table 3).

Rhizobium inoculation increased the rhizobium counts at 60 DAS and at harvest. Significantly highest rhizobium counts at 60 DAS and at harvest in soil were recorded with treatment $\mathrm{T}_{10}(\mathrm{FYM} 4 \mathrm{t} / \mathrm{ha}+$ Rhizobium + $\mathrm{PSB}+\mathrm{KSB}$ ) which remained statistically at par with the treatment $\mathrm{T}_{4}$ (FYM 4 t/ha + Rhizobium), $\mathrm{T}_{7}$ (FYM 4 t/ha + Rhizobium + PSB) and $\mathrm{T}_{8}(\mathrm{FYM} 4 \mathrm{t} / \mathrm{ha}+$ Rhizobium +
KSB). While, the lowest value of rhizobium counts were observed under the control treatment $\left(T_{1}\right)$. Significantly highest $N$ content in soil after harvest in fenugreek recorded with treatment $\mathrm{T}_{10}$ (FYM $4 \mathrm{t} / \mathrm{ha}+$ Rhizobium + PSB + KSB) and it was found statistically analogous with treatment $\mathrm{T}_{2}$ (2040-00 kg N-P $\mathrm{P}_{2} \mathrm{O}_{5}-\mathrm{K}_{2} \mathrm{O} / \mathrm{ha}$ ), $\mathrm{T}_{7}$ (FYM 4 t/ha + Rhizobium + PSB) and $\mathrm{T}_{8}(\mathrm{FYM} 4 \mathrm{t} / \mathrm{ha}+$ Rhizobium + KSB). While, the lowest value of $\mathrm{N}$ content in soil after harvest were observed under the control treatment $\left(\mathrm{T}_{1}\right)$. The increase in available nitrogen because of the FYM liberated carbon dioxide and organic acids, which increase the availability of nitrogen and Rhizobium inoculation increase the available $\mathrm{N}$ in the soil may be due to continuous symbiotically fixation of nitrogen by Rhizobium through production of organic acid and reducing the soil $\mathrm{pH}$. Similar observations were also recorded by Purbey and sen (2007). 
PSB applied as soil application increased the PSB counts at 60 DAS and at harvest. Significantly highest PSB counts at 60 DAS and at harvest was recorded under the treatment $\mathrm{T}_{10}(\mathrm{FYM} 4 \mathrm{t} / \mathrm{ha}+$ Rhizobium + $\mathrm{PSB}+\mathrm{KSB})$ and it was found statistically at par with treatment $\mathrm{T}_{5}(\mathrm{FYM} 4 \mathrm{t} / \mathrm{ha}+\mathrm{PSB}), \mathrm{T}_{7}$ (FYM 4 t/ha + Rhizobium + PSB) and $\mathrm{T}_{9}$ (FYM 4 t/ha + PSB + KSB). While, the lowest value of PSB counts were observed under the control treatment $\left(\mathrm{T}_{1}\right)$.

Significantly highest $\mathrm{P}_{2} \mathrm{O}_{5}$ content in soil after harvest in fenugreek recorded with treatment $\mathrm{T}_{10}(\mathrm{FYM} 4 \mathrm{t} / \mathrm{ha}+$ Rhizobium $+\mathrm{PSB}+\mathrm{KSB})$ and it was found statistically analogous with treatment $\mathrm{T}_{2}$ (20-40-00 kg N- $\left.\mathrm{P}_{2} \mathrm{O}_{5}-\mathrm{K}_{2} \mathrm{O} / \mathrm{ha}\right)$, $\mathrm{T}_{5}(\mathrm{FYM} 4 \mathrm{t} / \mathrm{ha}+\mathrm{PSB}), \mathrm{T}_{7}(\mathrm{FYM} 4 \mathrm{t} / \mathrm{ha}+$ Rhizobium + PSB) and $\mathrm{T}_{9}(\mathrm{FYM} 4 \mathrm{t} / \mathrm{ha}+\mathrm{PSB}$ $+\mathrm{KSB}$ ). While, the lowest value of $\mathrm{P}_{2} \mathrm{O}_{5}$ content in soil after harvest were observed under the control treatment $\left(\mathrm{T}_{1}\right)$. The increase in the available phosphorous might be due to the solubilising action of $P$. striata on fixed soil phosphorous through the production of organic acids and bringing down soil $\mathrm{pH}$. The results obtained in present study are in close conformity with the findings of Tagad et al., (2007).

KSB applied as soil application increased the KSB counts at 60 DAS and at harvest. Significantly highest KSB counts at 60 DAS and at harvest was recorded under the treatment $\mathrm{T}_{10}(\mathrm{FYM} 4 \mathrm{t} / \mathrm{ha}+$ Rhizobium + PSB + KSB) and it was found statistically at par with treatment $\mathrm{T}_{6}(\mathrm{FYM} 4 \mathrm{t} / \mathrm{ha}+\mathrm{KSB}), \mathrm{T}_{8}$ $(\mathrm{FYM} 4 \mathrm{t} / \mathrm{ha}+$ Rhizobium $+\mathrm{KSB})$ and $\mathrm{T}_{9}$ $(\mathrm{FYM} 4 \mathrm{t} / \mathrm{ha}+\mathrm{PSB}+\mathrm{KSB})$. While, the lowest value of KSB counts were observed under the control treatment $\left(\mathrm{T}_{1}\right)$.

Significantly highest $\mathrm{K}_{2} \mathrm{O}$ content in soil after harvest in fenugreek recorded with treatment $\mathrm{T}_{10}(\mathrm{FYM} 4 \mathrm{t} / \mathrm{ha}+$ Rhizobium $+\mathrm{PSB}+\mathrm{KSB})$ and it was found statistically analogous with treatment $\mathrm{T}_{2}\left(20-40-00 \mathrm{~kg} \mathrm{~N}-\mathrm{P}_{2} \mathrm{O}_{5}-\mathrm{K}_{2} \mathrm{O} / \mathrm{ha}\right)$, $\mathrm{T}_{6}(\mathrm{FYM} 4 \mathrm{t} / \mathrm{ha}+\mathrm{KSB}), \mathrm{T}_{8}(\mathrm{FYM} 4 \mathrm{t} / \mathrm{ha}+$ Rhizobium + KSB) and $\mathrm{T}_{9}(\mathrm{FYM} 4$ t/ha + $\mathrm{PSB}+\mathrm{KSB}$ ). While, the lowest value of $\mathrm{K}_{2} \mathrm{O}$ content in soil after harvest were observed under the control treatment $\left(\mathrm{T}_{1}\right)$. The response of KSB may be attributed to mobilization of $\mathrm{K}$ from soil because of secretion of organic acids by the bacterial strains, thereby enhanced the available $\mathrm{K}$ in the soil after harvest. The results of similar kind have also been reported by Han et al., (2006).

Based on one year experimental results, it seems quite logical to conclude that higher production of fenugreek (Gujarat Fenugreek2) can be obtained by application of FYM @ 4 t/ha + Seed treatment of Rhizobium @30 $\mathrm{ml} / \mathrm{kg}$ seed + Soil application of PSB + KSB @ $3 \mathrm{~L} / \mathrm{ha}$ each on medium black calcareous clayey soil under South Saurashtra Agroclimatic Zone.

\section{References}

Anonymous. District-wise area, production and yield of important food \& non- food crops in Gujarat State. Directorate of Agriculture, Gujarat State, Gandhinagar, 2018.

Bhunia, S. R., Chauhan, R. P. S., Yadav, B. S. and Bhati, A. S. 2006. Effect of phosphorus, irrigation and Rhizobium on productivity, water use and nutrient uptake in fenugreek (Trigonella foenum graecum L.). Ind. J. Agron., 51: 239241.

Han, H. S., Supanjani and Lee, K. D. 2006. Effect of co-inoculation with phosphate and potassium solubilizing bacteria on mineral uptake and growth of pepper and cucumber. Plant, Soil and Environment, 52(3): 130-136.

Khiriya, K. D. and Singh, B. P. 2003. Effect of phosphorus and farmyard manure on yield, yield attributes and nitrogen, 
phosphorus and potassium uptake of fenugreek (Trigonella foenum-graecum L.). Ind. J. Agron., 48: 62-65.

Lakpale, R., Shrivastava, G. K. and Tuteja, S. S. 2007. Direct and residual effect of levels of phosphorus with and without FYM and cowdung blending on productivity of spice, rice cropping system. Environment and Ecology, 25 (4): 739-744.

Patil, U. D., Dhanphule, S. S. and Arvadia, M. K. 2008. Effect of organic manure and inorganic fertilizers application on growth and yield attributes of fenugreek. International Journal of Plant Sciences, 3(1): 233-234.

Purbey, S. K. and Sen, N. L. 2007. Effect of bioinoculants and bioregulators on yield and nutrient uptake by fenugreek (Trigonella foenum-graecum L.). Indian J. Agric. Res, 41(2): 154-156.
Rajasekaran S, Ganesh S. K, Jayakumar K, Rajesh M, Bhaskaran C, Sundaramoorthy P. (2012). Biofertilizers- Current status of Indian agriculture. J Environ \& Bioen, 4(3), 176-81.

Sinha R. K, Valani D, Chauhan K. 2014. Embarking on a second green revolution for sustainable agriculture by vermiculture biotechnology using earthworms: reviving the dreams of Sir Charles Darwin. Int J Agric \& Biol, 1, 50-64.

Tagad, S. G., Srinivas, j., Vijay, S. Kale and Sanjeev Nayak. 2016. Effect of different organic nutrient sources on growth and yield of fenugreek. International Journal of Farm Sciences, 6(1): 97-101.

\section{How to cite this article:}

Raiyani, V.N., P.K. Chovatia and Kamani, K.B. 2019. Substitution of Chemical Fertilizers with Organic Manure and Biofertilizers in Fenugreek (Trigonella foenum-graecum L.) on Medium Black Calcareous Clayey Soil. Int.J.Curr.Microbiol.App.Sci. 8(07): 2350-2356.

doi: https://doi.org/10.20546/ijcmas.2019.807.288 